\title{
ECONOMIC GAINS FROM SOCIAL ENTREPRENEURSHIP DEVELOPMENT IN LATVIA
}

\author{
LĀsma Dobele ${ }^{1}$, Aina Dobele $^{2}$ \\ Latvia University of Agriculture (Latvia)
}

\begin{abstract}
Social enterprises are crucial for Europe and its economy. These enterprises significantly contribute to job creation (especially for socially sensitive groups) and accounts for about $6 \%$ of GDP across the European Union. In Latvia the role of social entrepreneurship is underestimated. The research aim is: based on the international experiences regarding social entrepreneurship, to determine economic gains of social businesses in Latvia. During the first year of developing social enterprises (2015) in Latvia, it is envisaged to establish 250 social enterprises, in which in total 1250 people will be employed, of which $50 \%$ will be individuals from socially sensitive groups. Thus, the social benefit burden in municipalities will decrease by EUR 61 thousand, while almost EUR 222 thousand will be collected by the national government. The total gain from social entrepreneurship will amount to EUR 1.5 million over a six year period (2015-2020).

KEY WORDS: social entrepreneurship, social business, government.
\end{abstract}

JEL CODES: A10, H70, O12

DOI: http://dx.doi.org/10.15181/rfds.v14i3.861

\section{Introduction}

The European Commission has placed the social economy and social innovation at the heart of its concerns under the Europe 2020 strategy. In 2011, the European Commission launched the Social Business Initiative as part of the Single Market Act within which social enterprise is one of 12 priority areas. Social enterprise accounts for about $6 \%$ of GDP across the European Union (EU) and the European Commission's 'Europe 2020' Strategy sets a target for this contribution to grow to $9 \%$ of GDP over the decade to 2020. The importance of social entrepreneurship is based on its social and economic functions in economy. It has a great potential in reduction of poverty (Yunus, 2003: 15; Yunus, 2007: 20; Defourny, 2004: 3) and promotion of employment (especially for socially sensitive groups of people). Social enterprises employ socially sensitive groups of people with a relatively low employment rate, thereby contributing to the reintegration of socially excluded employees into the labour market (Emmerich, 1997: 100; Barraket, 2008: 4; Yunus, 2010: 35). However, there is lack of scientific researches where economic gains from social entrepreneurship development are explored.

Social entrepreneurship has gained recognition in EU and national policies, scientific research, education, and the commercial sector. More and more social enterprises of various kinds emerge in the world. In

1 Lāsma Dobele - doctor, assistant professor, Latvia University of Agriculture, Faculty of Economics and Social Development. Scientific interests: social entrepreneurship

E-mail: Lasma.Dobele@1lu.lv

2 Aina Dobele - doctoral student, Latvia University of Agriculture, Faculty of Economics and Social Development. Scientific interests: economic resources

E-mail: Aina.Dobele@1lu.lv 
the European countries, the experiences are different regarding social enterprises. In United Kingdom, the sector of social enterprise is significantly developed. Approximately 70,000 social enterprises exist in the country, contributing an estimated EUR 30 billion to the national economy. In Lithuania, the legislative process of social entrepreneurship is much ahead of other European countries. The Law on Social Enterprises which was passed in 2004 details the process of receiving the social enterprise status, defines target groups of the persons employed in a social enterprise, and sets the rights and duties of a social enterprise. In addition, it defines the boundaries between "social enterprise" and "social enterprises of the disabled" which also exists in Lithuania and is also described by this Law. In Ireland it is extremely difficult to estimate the potential employment for the social enterprise sector, as it is not certain the degree to which funding or services might be provided by the sector overall, but it is estimated that there could be at least 1400 social enterprises.

An opinion exists that social enterprises is the future of any economy, yet, there are a few social entrepreneurs in Latvia, besides, the concept of social entrepreneurship is a new one. There are no legal and institutional frameworks, no support instruments for fostering its development in Latvia. Furthermore, there is no single understanding regarding defining the concept of social entrepreneurship. Within the present research, social entrepreneurship is defined as a kind of entrepreneurship, the priority of which is to create social values and form economic protection for socially sensitive groups (Dobele, 2013: 70). To foster social entrepreneurship in Latvia it is important to examine the economic gains of social entrepreneurship to show its significance in national and municipal level.

The research object is economic gains of social entrepreneurship. The purpose of the research paper: based on the international experiences regarding social entrepreneurship, to determine economic gains of social businesses in Latvia.

To achieve the purpose, the following tasks were set:

- to examine the economic contribution of social enterprises in European countries;

- to examine the economic gains of social entrepreneurship at the national and municipal levels in Latvia.

The following research methods were employed to achieve the aim and fulfil the tasks: the descriptive method was employed to shape the theoretical discussion and interpret the research results based on the scientific findings on social entrepreneurship; analysis and synthesis were employed to examine individual problem elements and identify connections among them; descriptive statistics and time series analysis - were employed to analyse the social enterprise contribution to the national and local budget.

\section{The social enterprise contribution to the economy in European countries}

According to the European Commission data, the EU has more than 2 million social enterprises, which employ $6 \%$ of the working population. In the EU Member States, social entrepreneurship consists of 4-7 \% of GDP and employs more than 5 million people. Countries that recognise and value social enterprise as part of the 'real' economy have achieved significant growth in employment and output in the sector while addressing genuine social and environmental needs (Adding Value Delivering (...), 2013: 3). Given the fact that in Latvia is lack of information about social enterprises and its contribution to the economy, it is important to explore the international experiences. However, it should be mentioned, that assessing the scale of social enterprises is hampered by varying definitions of the social enterprises in the countries, and also by the nature of their role, which is driven by political and social ideologies of different countries.

The economic indicators of social enterprises in European countries are presented in Table 1. 
Table 1. The economic indicators of social enterprises in European countries

\begin{tabular}{|c|c|c|c|c|c|c|}
\hline \multirow{2}{*}{ Country } & \multirow{2}{*}{$\begin{array}{c}\text { Number } \\
\text { of social } \\
\text { enterprises }\end{array}$} & \multicolumn{2}{|c|}{ Number of employees } & \multirow{2}{*}{$\begin{array}{c}\text { Annual } \\
\text { turnover } \\
\text { for social } \\
\text { enterprise, } \\
\text { EUR }\end{array}$} & \multirow{2}{*}{$\begin{array}{c}\text { Social } \\
\text { entrepreneurship } \\
\text { in GDP structure, } \\
\%\end{array}$} & \multirow{2}{*}{$\begin{array}{c}\text { Contribution to } \\
\text { the state budget, } \\
\text { EUR }\end{array}$} \\
\hline & & $\begin{array}{c}\text { All } \\
\text { employees }\end{array}$ & $\begin{array}{l}\text { Special } \\
\text { target } \\
\text { groups }\end{array}$ & & & \\
\hline $\begin{array}{l}\text { United Kingdom } \\
\text { (2013) }\end{array}$ & 70000 & 1 million & $\cdots$ & 232000 & 5 & 30 billion \\
\hline Ireland (2011) & 1400 & \begin{tabular}{|l|}
2500 \\
-33000
\end{tabular} & $\cdots$ & 1.4 billion & 3 & 1.9 billion \\
\hline $\begin{array}{l}\text { Finland } \\
\text { (2011) }\end{array}$ & 158 & 1200 & 750 & $\ldots$ & $\cdots$ & $\ldots$ \\
\hline Lithuania (2012) & 137 & 5400 & 3900 & $\ldots$ & $\ldots$ & $\ldots$ \\
\hline
\end{tabular}

Source: Social Enterprise UK (...), 2013: 10; The Economic and (...), 2011: 15; Ščerbickaite, Moskvina, 2013: 5; Lindberg, 2011: 12.

United Kingdom. The social enterprise sector is growing rapidly in the United Kingdom. Recent government estimates suggest there are 70,000 social enterprises in the United Kingdom, employing around a million people in 2013. The sector's contribution to the economy has been valued at over EUR 30billion (Social Enterprise UK (...), 2013: 10). The United Kingdom is a pioneer when it comes to social enterprise and the social investment that helps finance it, attracting the interest of international practitioners and policymakers alike.

An average annual turnover of social enterprises were EUR 300000 in 2011. However, social enterprises are not immune to the economic headwinds affecting equivalent SMEs. The turnover of social enterprises has decreased by $29 \%$ (2011-2013) (Social Enterprise UK (..), 2013: 15; Social Enterprise UK (..), 2011: 10). The combined turnover of the top 100 United Kingdom social enterprises grew by $85 \%$ (2012-2013) to EUR 400 million in an economy that is shrinking. Two-thirds of British social enterprises are making a profit, and a further 16 percent are breaking even.

According to the Social Enterprise UK survey (2013) mostly these are micro or small enterprises employing less than 10 people. $84 \%$ of small businesses employ 1-9 people, $14 \% 10-49$ people and only $2.5 \%$ more than 50. This suggests that social enterprises employ more people relative to turnover than mainstream small business. In the survey authors assume that this is not simply based on socialenterprises employing people on low wages. It can be explained by the fact that many small economic units produces high added value (Social Enterprise UK (...), 2013: 49). The majority (52\%) of social enterprises actively employ people who are disadvantaged in the labour market (for example: the long-term unemployed, ex-offenders, people with disabilities). It should be mentioned that social enterprises are very heavily concentrated in the United Kingdom's most deprived communities.

Ireland. Social business expert Michael Pyner (2012) believes that social enterprises are suitable type of business for Latvia. "Latvia is a small country, which in this case can be considered as an advantage because it can be easier and quicker to respond to changes comparing with a great country." As successful examples of social entrepreneurship promotion, he points out Ireland. Social enterprise has a strong and growing presence in Ireland, building on deep roots of community organisation, self-help and a native enthusiasm for enterprise. Within this, the social enterprise sector employs between 25,000 and 33,000 people in over 1,400 social enterprises (The Economic and (...), 2011: 15), with a total income of around EUR 1.4 billion representing $3 \%$ of GDP. Social enterprise is a small but growing part of the enterprise base and ecosystem that has potential to bring further job gains and deliver economic potential (Social enterprise in (...), 2013: 2). Besides, if Ire- 
land's social enterprise sector were to approach mean EU levels of output ( $6 \%$ of GDP), it is estimated that there would be approximately 65,000 jobs in social enterprises; this figure could grow to as much as 100,000 jobs if Ireland achieved the $9 \%$ goal set by the EU under the 'Europe 2020' Strategy (Clarke, Eustace, 2009: 63). In order to reach the average level of employment in social business, is expected to create an average of 5,000 jobs in the next five years (200 new jobs in the first year, 450, and 850 in the second year - the third year, a total of 1,500 jobs). However, to achieve the following, social entrepreneurship requires a proper regulatory framework and support tools.

It should be mentioned that in Ireland credit unions are excluded from the statistics of social enterprises, although they are considered to be social enterprises. It is because the credit union movement alone has almost 3 million members, over 500 local organisations, employs some 3,000 people, has combined assets of EUR 15.1 billion and combined savings of EUR 11.9 billion (Adding Value Delivering (...), 2013: 5).

The nature of social enterprises In Ireland is such that goods and services tend to be provided locally and so the jobs are created in local communities. They can provide jobs across a range of skill-sets also, some with the specific objective of providing employment to those most marginalised. Among the benefits of social enterprises are that they can provide jobs to those most distant from the labour market, both spatially and socially. As well as multiplier effects from the direct jobs in the sector, further indirect jobs are created either by enabling the development of other enterprises, for example by social enterprises that assist economic and community development, or by providing services that bring people to a community such as local festivals or community-run hostels.

Lithuania. The government has created an adequate legal framework for regulating social entrepreneurship and has introduced support instruments for fostering its development. Law on Social Enterprises launched in 2004 and it provides the following definition of social enterprise: Social enterprise is a legal entity of any form (individual enterprise, joint stock company, public institution) that satisfies the following conditions:

- the workers belonging to the target groups constitute no less than 40 percent of total staff and the number of such employees is not less than 4 ;

- the activities for development of professional and social skills and social integration are implemented;

- the incomes from unfunded activities of social enterprises comprise no more than 20 percent.

The Law on Social Enterprises also provides the definition of social enterprise for disabled, where the share of disabled target group consists of at least 50 percent of the annual average number of employees with special stress on support for severely disabled people.

In 200426 companies got the status of social enterprises. Since 2004 the number of social enterprises extended to 137 in 2012 (Disabled Social firms - 78; Social firms - 59 (people excluded from the workforce i.e. lonely parents, imprisoned etc.). Despite the fast growth of the number of social enterprises during the last years they constitute only $0.002 \%$ of all economic entities operating in the country (Ščerbickaite, Moskvina, 2013: 5).

The key objective of social enterprises in Lithuania is employment of vulnerable groups. Since the Law on Social firms was put in place in 2004 the number of employed disabled people increased 4.5 times. In 2012137 social firms employed 5,400 employees in total out of which 3,900 are in the target groups (i.e. disabled people, long - term unemployed, imprisoned people, lonely parents etc.). However people with disabilities employed in social enterprises represent $0.08 \%$ of all employed disabled people. It should be mentioned, that the share of the employed people with severe disabilities is higher in social enterprises than in the open labour market. Unfortunately, Lithuanian social enterprises fail to employ vulnerable target groups of unemployed other than disabled (other vulnerable groups constitute only $0.2 \%$ ) (Ščerbickaite, Moskvina, 2013: 5).

Social enterprises and employees in Lithuania in the period 2004-2012 are presented in Fig. 1. 


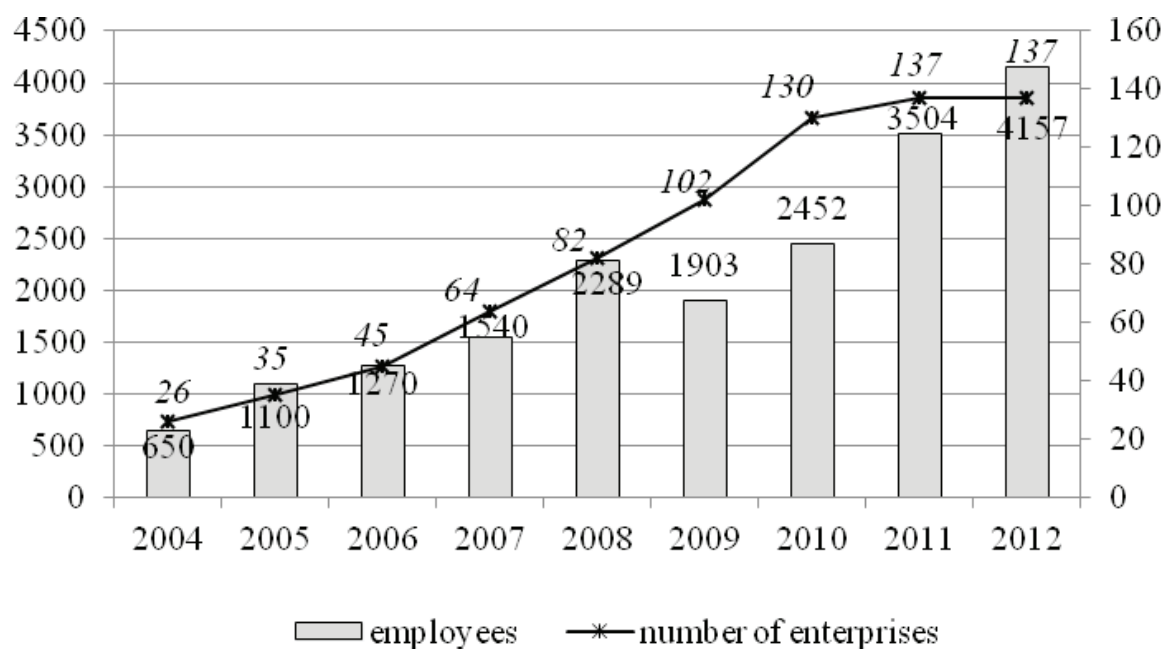

Figure 1. Social enterprises and employees in Lithuania in the period 2004-2012

Source: Ščerbickaite, Moskvina, 2013: 5.

Social firms are entitled to corporate tax relief (15\%) and various subsidies (including payroll, social insurance relief, transportations, employment, etc.). Most of social enterprises are micro, small and medium size private companies. More than half of them belong to the sector of manufacturing (Moskvina, 2013: 52).

Finland. Act on Social Enterprises (1351/2003, revised 924/2012), actually "social firms" or "work integration social enterprises", provide employment opportunities particularly for persons with disabilities and the long-term unemployed. In the definition of the law, having fulfilled the criteria, the social enterprise (or "firm") is a registered trader which is entered in the register of social enterprises. There are 158 work integration social firms (Seppelin, Kostilainen, 2013: 2). These enterprises employ 1,200 people, of which 750areofspecialtarget groups (people with disabilities and long-term unemployed) (Lindberg 2011: 12). Number of persons employed in crease slowly, mainly be cause social enterprises are micro or small enterprises.

\section{Economic gains at municipal and national level from social entrepreneurship in Latvia}

To identify the gains from social entrepreneurship in Latvia in quantitative terms, it is important to estimate financial gains of the central and local governments from social entrepreneurship. Given the fact that statistical data on social entrepreneurship are not collected in Latvia, the calculations were performed based on international experiences (mainly in Ireland and Lithuania).

The year 2015 is set as the first year of operation of social enterprises in Latvia, as, according to the Communication from the European Commission (2011) "Social Business Initiative Creating a favourable climate for social enterprises, key stakeholders in the social economy and innovation", it is envisaged to allocate funding for social enterprises from the EU Structural Funds in 2014, which can foster the development of social entrepreneurship in Latvia. It means that the first considerable estimates regarding the operation of social enterprises may be performed for the period starting with 2015.

Number of social enterprises. It is envisaged that 250 social enterprises might be established in Latvia in 2015. Based on the experience in Ireland, it is important to increase the number of social enterprises from year to year to increase employment in social entrepreneurship. It is assumed that on average the number of social enterprises will annually increase by 50 units.

Size of social enterprises and their number of employees. According to the experiences of European countries, most social enterprises employ on average less than 9 employees. The social enterprise mostly corresponds to a micro- or a small enterprise, and during the first years of operation it employs on average 5 employees. Based on the international experiences, one can assume that if developing social entrepreneurship, during the first year in Latvia, approximately 1250 new jobs will be created, of which $50 \%$ 
are occupied by individuals from socially sensitive groups (according to the experience of Lithuania, they are mainly the disabled). Over a period of six years (until 2020), it is envisaged to create on average 4000 jobs.

Economic indicators of social enterprises. Investment in social enterprise consists of around EUR 5,700 (Dobele, 2013: 106) which means that total investment for new social enterprises in the 2015 will build EUR 1.4 million (including subsidies for new social enterprises). To determine the net turnover of social enterprises, there were used multiplier 1.32 proposed of DKM Economic Consultants (The economic and (...), 2011:24). This means that for every euro injected into the economy by a social business, the economy benefits to the tune of an additional 32 cent. It means that every euro invested into the social enterprises constitutes revenue of EUR 1.32. Profit is reinvested in the social business and it is calculated using the average profitability of micro firms $-10 \%$. Given the fact that profit is reinvested into the company, there will be rise in investment and business scope, which indicates on the need for additional staff. The calculation of economic indicators for social enterprises are presented in Table 2.

Table 2. The forecast of social enterprise economic indicators in Latvia in the period 2015-2020, EUR

\begin{tabular}{|c|c|c|c|c|c|c|c|}
\hline \multirow{2}{*}{ Year } & \multirow{2}{*}{$\begin{array}{c}\text { Number } \\
\text { of social } \\
\text { enterprises }\end{array}$} & \multicolumn{2}{|c|}{$\begin{array}{l}\text { The average number } \\
\text { of persons employed } \\
\text { in social enterprises }\end{array}$} & \multicolumn{2}{|c|}{ Investment, EUR } & \multirow{2}{*}{$\begin{array}{l}\text { Net sales, } \\
\text { EUR } \\
(6 . x 1.32)\end{array}$} & \multirow{2}{*}{$\begin{array}{c}\text { Profit for } \\
\text { reinvestment, } \\
\text { EUR } \\
(7 . x 0.1)\end{array}$} \\
\hline & & $\begin{array}{c}\text { In one } \\
\text { social } \\
\text { enterprise }\end{array}$ & $\begin{array}{l}\text { In Latvia } \\
\text { in total }\end{array}$ & $\begin{array}{c}\text { In one } \\
\text { social } \\
\text { enterprise }\end{array}$ & $\begin{array}{c}\text { In Latvia } \\
\text { in total } \\
(2 . x 5 .)\end{array}$ & & \\
\hline 1. & 2. & 3. & 4. & 5. & 6. & 7. & 8. \\
\hline 2015. & 250 & 5 & 1250 & 4000 & 1000000 & 1320000 & 132000 \\
\hline 2016. & 300 & 5 & 1500 & 4500 & 1357000 & 1791240 & 179124 \\
\hline 2017. & 350 & 7 & 2450 & 5000 & 1786124 & 2357684 & 235768 \\
\hline 2018. & 400 & 7 & 2800 & 5500 & 2296892 & 3031898 & 303190 \\
\hline 2019. & 450 & 8 & 3600 & 6000 & 2900082 & 3828108 & 382811 \\
\hline 2020. & 500 & 8 & 4000 & 6500 & 3607893 & 4762419 & 476242 \\
\hline $\begin{array}{c}2020 . / \\
2015 ., \%\end{array}$ & 100 & 60 & 220 & 1.6 & 300 & 260.8 & 260.8 \\
\hline
\end{tabular}

Source: authors' calculations

By developing social entrepreneurship in Latvia, considerable gains may be expected at the municipal and national levels. National economic gains result from the state mandatory social insurance contributions (SMSIC), the personal income tax (PIT), and the business risk state fee. Municipal economic gains result from the reduction of the burden of social benefits (guaranteed minimal income (GMI) benefits and housing benefits) if social enterprises employ individuals from socially sensitive groups. The social enterprise created economic contribution to the national and municipal budget in the period 2015-2020 are summarizes in the Table 3 .

Table 3. The projected social enterprise contribution to the national and local budget in the period 2015-2020, EUR

\begin{tabular}{|l|l|l|l|l|l|l|l|l|}
\hline \multirow{2}{*}{ Year } & \multirow{2}{*}{ Salaries } & \multirow{2}{*}{$\begin{array}{l}\text { Number of } \\
\text { employees }\end{array}$} & & \multicolumn{2}{c|}{ Government revenue and expenditure, EUR } & \multicolumn{2}{c|}{ Municipal gains, EUR } \\
\cline { 6 - 11 } & & & SIT & $\begin{array}{c}\text { Business } \\
\text { risk state fee }\end{array}$ & Subsidies & GMI benefit & $\begin{array}{c}\text { Housing } \\
\text { benefit }\end{array}$ \\
\hline 2015. & 320 & 1250 & +136363 & +85925 & +450 & -711250 & +31125 & +29606 \\
\hline 2016. & 390 & 1500 & +199425 & +125655 & +540 & -142250 & +37350 & +35528 \\
\hline 2017. & 460 & 2450 & +384185 & +242085 & +882 & -142250 & +61005 & +58028 \\
\hline 2018. & 530 & 2800 & +505904 & +318752 & +1008 & -142250 & +69720 & +66318 \\
\hline 2019. & 600 & 3600 & +736 & +463968 & +1296 & -142250 & +89640 & +85266 \\
\hline 2020. & 670 & 4000 & +913600 & +575680 & +1440 & -142250 & +99600 & +94740 \\
\hline $2020 . / 2015 ., \%$ & 109.4 & 220.0 & 570.0 & 570.0 & 220.0 & -80.0 & 220.0 & 220.0 \\
\hline
\end{tabular}

Source: author's calculations and construction 
SMSIC estimates. The estimates of revenues from the SMSIC, the PIT, and the business risk state fee were based on the minimal (gross) average monthly wage in Latvia, which is EUR 320 in 2014. It is assumed that the average wage at social enterprises is increased every year. The rate of SMSIC paid by employers is $23.59 \%$, while the employee SMSI Crate is $10.5 \%$ in 2014. To estimate the national gains from the SMSIC paid by social enterprises, the following formula was used:

$G_{t_{-} \text {SMSIC }}=G_{\text {SMSIC }} * N$,

where: $G_{t_{-} S M S I C}-$ total SMSIC; $G_{\text {SMSIC }}-$ SMSIC per employee; $N$ - number of employees per social enterprise.

During the first year, employing on average 1250 employees at social enterprises, the revenue from the SMSIC amounts to on average EUR 136 thousand (on average EUR 109 per employee). Assuming that wages increase every year, the revenue from theSMSIC paid to the national government will increase 7 times until 2020.

PIT estimates. The estimate is based on the PIT rate of $24 \%$ (in 2014). To calculate the total PIT revenue received by the Treasury from employees of social enterprises, the following formula was used:

$$
G_{t_{P} P I T}=G_{P I T} * N,
$$

where: $G_{t-P I T}-$ PIT revenue collected from all employees; $G_{P I T}-$ PIT revenue per employee; $N$ - number of employees.

If employing on average 1250 employees at social enterprises, in the first year, on average EUR86 thousand will be paid to the Treasury (on average EUR 70 per employee). Assuming that wages increase every year, the revenue from the PIT paid to the national government will increase almost 7 times until 2020.

Business risk state fee estimates. Assuming that the kind of contract made by employees of social enterprises is a labour contract, a business risk state fee of EUR 0.36 has to be paid. If employing on average 1250 employees at social enterprises, the Treasury will receive EUR 450 (EUR0.36 per employee). To estimate the total revenue from the business risk state fee paid by employees of social enterprises, the following formula was used:

$$
G_{t f e e}=G_{f e e} * N \text {, }
$$

where: $G_{t f e e}$ - total revenue from the business risk state fee collected from social enterprises; $G_{f e e}$ - business risk state fee per employee; $N$ - number of employees.

The total tax revenuecollected from employees of social enterprises and paid to the Treasury in 2015 will amount to EUR 223 thousand, while in 2020 - almost EUR 1.5 million.

Municipal economic gains involve the reduction of the burden of social benefits (guaranteed minimal income (GMI) benefits and housing benefits) if social enterprises employ individuals from socially sensitive groups.

GMI benefit estimates. The target group of social entrepreneurship is the individuals from socially sensitive groups whose income is very low, therefore, such persons are often granted GMI benefits. Since 1 January 2013, an equal GMI benefit of EUR 49.80 has been set for all low-income individuals (in 2012 it was EUR56.91 for adults and EUR 64.03 for children), and the national government does not allocate funding for these benefits. It causes a considerable tax burden on local authorities, given the large number of low-income individuals in the country. Assuming that $50 \%$ of the employees of social enterprises are low-income persons who very often receive GMI benefits, by promoting their employment, the income level of such people will increase, while the tax burden on local authorities during the first year of operation of social enterprises will decline by almost EUR 31 thousand, and in 2020 it will reach almost EUR 100 thousand. 
Housing benefit estimates. The Social Service and Social Assistance Law stipulates that the size of housing benefits, the procedure of paying the benefits, and individuals who are eligible for the benefits are regulated by the binding municipal regulations. Most often, individuals from socially sensitive groups, whose income is very low, apply for housing benefits. The size of housing benefits is differentiated in municipalities. The average size of housing benefits per person in Latvia in 2013 was equal to EUR 47.37. Assuming that individuals from socially sensitive groups are employed at social enterprises and their income increase, in 2015 municipalities could save on housing benefits almost EUR 30 thousand, while in 2020 - EUR95 thousand.

The economic gains from developing social entrepreneurship at the national and municipal levels are shown in Fig. 2.

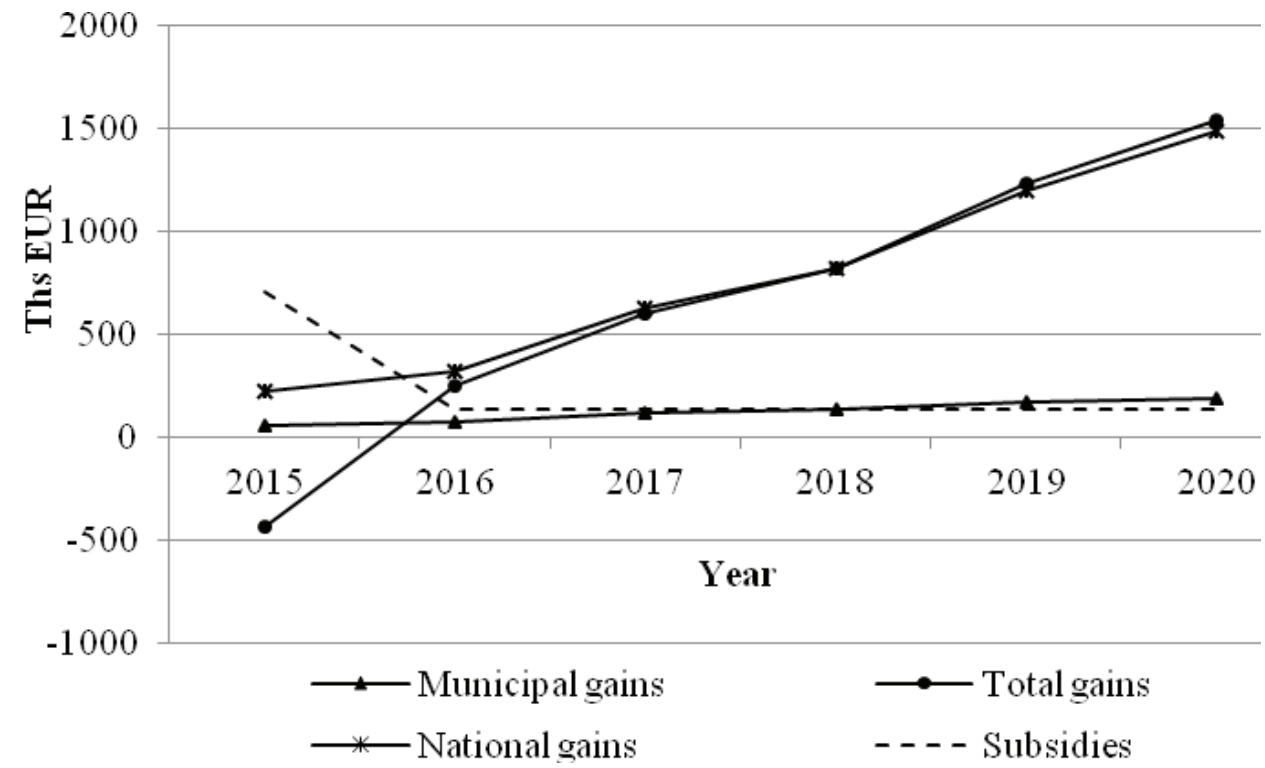

Figure 2. Economic gains from developing social entrepreneurship in Latvia in the period 2015-2020, ths EUR

Source: author's calculations and construction

The calculations reveal that by employing individuals from socially sensitive groups at social enterprises, the national and municipal financial gains will be equal to approximately EUR 283 thousand during the first year of the operation of social enterprises. Yet, given the fact that it is important to provide financial aid for establishing social enterprises, a subsidy of EUR 2845 to purchase capital assets has to be granted to new social enterprises. It implies that during the first year of the operation of social enterprises, the government will suffer a loss of EUR 428 thousand. Since the subsidies are granted only to new social enterprises, according to the forecast, the tax revenue from their operation will increase, reaching EUR 1.5 million in 2020.

\section{Conclusions}

Social entrepreneurship is a kind of entrepreneurship, the priority of which is to create social values and form economic protection for socially sensitive groups. Internationally, social enterprise is considered to be vital part of the country's economy. In the United Kingdom recognises it as a distinct sector, in Lithuania law has been introduced over the past 10 years to support and encourage the development of social enterprises. It is proved that social enterprises can play an important role in economy. The social enterprise sector has the potential to represent at least $5 \%$ of GDP and promote the job creation, especially for socially sensitive groups of people. 
In Latvia the social entrepreneurship is seriously underdeveloped and underestimated. There are no legal and institutional frameworks for it. However, social entrepreneurship can give significant economic benefit to the national and municipal budget. Base on international experiences, there were made calculations on potential economic gain from social entrepreneurship in Latvia. During the first year of developing social enterprises (2015), it is envisaged to establish 250 social enterprises in Latvia, in which in total 1250 people will be employed, of which $50 \%$ will be individuals from socially sensitive groups. Thus, the social benefit burden in municipalities will decrease by EUR 61 thousand, while almost EUR 222 thousand will be collected by the national government during the first years of operation of social enterprises. The total gain from social entrepreneurship will amount to EUR 1.5 million over a six year period (2015-2020).

\section{References}

Adding Value Delivering Change. The Role of Social Enterprise in National Recovery. (2010). Report of the Social Enterprise Task Force. Clann Credo, Dublin Employment Pact.

Barraket, J. (2008). Social Inclusion, Employment and Social Enterprise. Fitzroy VIC: Brotherhood of St Laurence Research and Policy Centre.

Defourny, J. (2004). From Third Sector to Social Enterprise. In: C. Borzaga, J. Defourny. The Emergance of Social Enterprise. London: Routledge, p. 1-28.

Dobele, L. (2013). Social entrepreneurship development possibilities in Latvia. Doctoral dissertation. Jelgava.

Emmerich, M. (1997). Making a Virtue of Necessity? The Role of Intermediate Labour Markets. Local Economy, Vol. 12, No. 2, p. $98-103$.

Europe 2020. A European strategy for smart, sustainable and inclusive growth. (2010). European Commission. Brussels.

Law on Social Enterprises. (2004). Official Gazette, No. 96-3519.

Lindberg, J. (2011). Social Employment in Finland.The role of workshops and social firms in the employment of disabled persons. VATES Foundation.

Moskvina, J. (2013). Social enterprises as a tool of social and economic policy. Lituanian case. Entrepreneurship and Sustainability Issues, Vol. 1, No. 1, p. 45-54.

Seppelin, M., Kostilainen, H. (2013). Social entrepreneurship and other models to secure employment for those most in need. Country paper - Finland. Comments paper. Croatia.

Single Market Act. Twelve levers to boost growth and strengthen confidence. "Working together to create new growth". (2011). European Commission. Brussels.

Social Business Initiative Creating a favourable climate for social enterprises, key stakeholders in the social economy and innovation. (2011). European Commission. Brussels.

Social enterprise in Ireland. Sectoral opportunities and policy issues. (2013). Forfas.

Social Enterprise UK. Fightback Britain. (2011). A Report on the State of Social Enterprise Survey. 2011.

Social Enterprise UK. The people's business. (2013). State of Social Enterprise Survey 2013.

Social Service and Social Assistance Law. (2002). The Parliament of the Republic of Latvia.

Ščerbickaite, K., Moskvina, J. (2013). Social entrepreneurship and other models to secure employment for those most in need. Social enterprises in Lithuania. Comments paper. Croatia.

Straustiņa, I. (2012). Bremzeskapitālismam. Available at: http://politika.lv/article/bremzes-kapitalismam.

The Economic and Social Contribution of Clann Credo - the Social Investment Fund. (2011). Dublin: DKM Economic Consultants.

Yunus, M. (2003). Banker to the Poor: Micro-Lending and the Battle against World Poverty. New York: Public Affairs.

Yunus, M. (2010). Building Social Business: The New Kind of Capitalism that Serves Humanity's Most Pressing Needs. New York: Public Affairs.

Yunus, M. (2007). Creating a World Without Poverty. Social Business and the Future of Capitalism. New York: Public Affairs. 


\section{SOCIALINĖS ENTREPRENERYSTĖS PLE்TROS LATVIJOJE EKONOMINÉ NAUDA}

\section{LĀsma Dobele, Aina Dobele}

Latvijos žemės ūkio universitetas (Latvija)

\section{Santrauka}

Socialinès įmonès yra svarbios Europai ir jos ekonomikai. Šios organizacijos prisideda prie darbo vietu kūrimo (ypač socialiai jautrioms grupėms) ir sukuria apie $6 \%$ Europos Sajungos BVP. Tuo tarpu Latvijoje socialinès entreprenerystės vaidmuo nepakankamai įvertintas. Šio tyrimo tikslas - remiantis tarptautine patirtimi socialinės entreprenerystės srityje, nustatyti jų teikiamą ekonominę naudą Latvijoje. 2015 metais Latvijoje numatyta ịsteigti 250 socialinių įmonių, kuriose būtų įdarbinta 1250 žmonių, 50 \% iš jų sudarys žmonès iš socialiai jautrių grupių. Taigi savivaldybių išlaidos socialinei paramai sumažès 61000 eurų, 222000 eurų bus papildomai surinkta ị valstybès biudžetą. Bendra ekonominé nauda sudarys 1500000 eurų per šešerių metų laikotarpi.

PAGRINDINIAI ŽODŽIAI: socialine entreprenerystè, socialinis verslas, vyriausybè.

JEL KLASIFIKACIJA: A10, H70, O12 